\title{
Precursors for carbon doping of GaN in chemical vapor deposition
}

\author{
Xun Li, Örjan Danielsson, Henrik Pedersen, Erik Janzén and Urban Forsberg
}

\section{Linköping University Post Print}

\section{Tweet}

N.B.: When citing this work, cite the original article.

Original Publication:

Xun Li, Örjan Danielsson, Henrik Pedersen, Erik Janzén and Urban Forsberg, Precursors for carbon doping of $\mathrm{GaN}$ in chemical vapor deposition, 2015, Journal of Vacuum Science \& Technology B, (33), 2, 021208.

http://dx.doi.org/10.1116/1.4914316

Copyright: American Institute of Physics (AIP)

http://www.aip.org/

Postprint available at: Linköping University Electronic Press

http://urn.kb.se/resolve?urn=urn:nbn:se:liu:diva-117385 


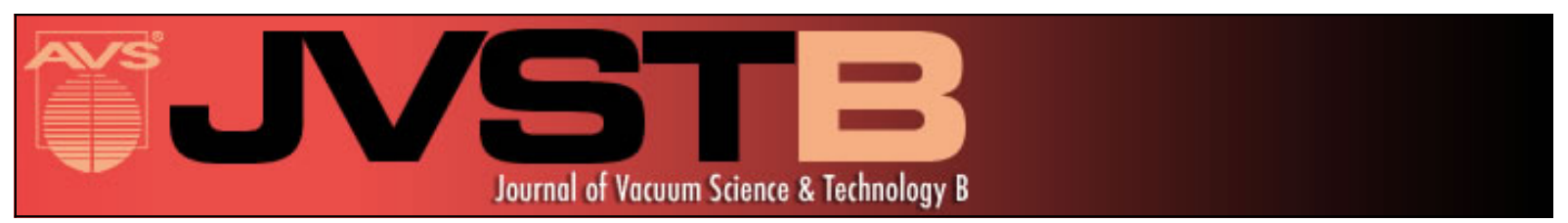

\section{Precursors for carbon doping of $\mathrm{GaN}$ in chemical vapor deposition}

Xun Li, Örjan Danielsson, Henrik Pedersen, Erik Janzén, and Urban Forsberg

Citation: Journal of Vacuum Science \& Technology B 33, 021208 (2015); doi: 10.1116/1.4914316

View online: http://dx.doi.org/10.1116/1.4914316

View Table of Contents: http://scitation.aip.org/content/avs/journal/jvstb/33/2?ver=pdfcov

Published by the AVS: Science \& Technology of Materials, Interfaces, and Processing

\section{Articles you may be interested in}

Metalorganic chemical vapor deposition growth of high-mobility AIGaN/AIN/GaN heterostructures on GaN templates and native GaN substrates

J. Appl. Phys. 117, 085301 (2015); 10.1063/1.4913223

Strain effects on In x Al $1-x$ N crystalline quality grown on GaN templates by metalorganic chemical vapor deposition

J. Appl. Phys. 107, 043515 (2010); 10.1063/1.3305397

Growth of single crystalline GaN thin films on Si(111) substrates by high vacuum metalorganic chemical vapor deposition using a single molecular precursor

J. Vac. Sci. Technol. B 22, 2144 (2004); 10.1116/1.1775193

Effect of dislocations on luminescence properties of silicon-doped GaN grown by metalorganic chemical vapor deposition method

J. Vac. Sci. Technol. B 22, 624 (2004); 10.1116/1.1667509

Growth of Si delta-doped GaN by metalorganic chemical-vapor deposition

Appl. Phys. Lett. 77, 2195 (2000); 10.1063/1.1314883

\section{SHIMADZU Powerful, Multi-functional UV-Vis-NIR and Excellence in Science FTIR Spectrophotometers}

Providing the utmost in sensitivity, accuracy and resolution for applications in materials characterization and nano research

- Photovoltaics

- Polymers

- Thin films

- Paints

- Ceramics

- DNA film structures

- Coatings

- Packaging materials
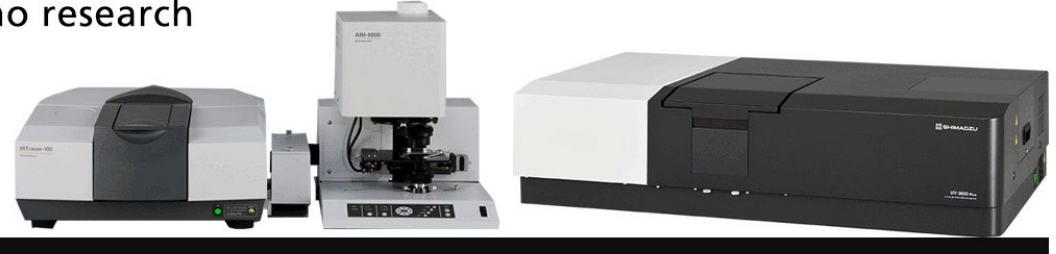


\title{
Precursors for carbon doping of GaN in chemical vapor deposition
}

\author{
Xun Li, ${ }^{a}{ }^{a}$ Örjan Danielsson, Henrik Pedersen, Erik Janzén, and Urban Forsberg \\ Department of Physics, Chemistry and Biology, Linköping University, SE-581 83 Linköping, Sweden
}

(Received 6 December 2014; accepted 20 February 2015; published 9 March 2015)

\begin{abstract}
Methane $\left(\mathrm{CH}_{4}\right)$, ethylene $\left(\mathrm{C}_{2} \mathrm{H}_{4}\right)$, acetylene $\left(\mathrm{C}_{2} \mathrm{H}_{2}\right)$, propane $\left(\mathrm{C}_{3} \mathrm{H}_{8}\right)$, iso-butane $\left(\mathrm{i}-\mathrm{C}_{4} \mathrm{H}_{10}\right)$, and

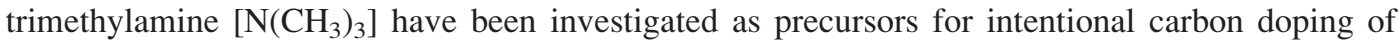
(0001) GaN in chemical vapor deposition. The carbon precursors were studied by comparing the efficiency of carbon incorporation in $\mathrm{GaN}$ together with their influence on morphology and structural quality of carbon doped GaN. The unsaturated hydrocarbons $\mathrm{C}_{2} \mathrm{H}_{4}$ and $\mathrm{C}_{2} \mathrm{H}_{2}$ were found to be more suitable for carbon doping than the saturated ones, with higher carbon incorporation efficiency and a reduced effect on the quality of the GaN epitaxial layers. The results indicate that the $\mathrm{C}_{2} \mathrm{H}_{2}$ molecule as a direct precursor, or formed by the gas phase chemistry, is a key species for carbon doping without degrading the $\mathrm{GaN}$ quality; however, the $\mathrm{CH}_{3}$ species should be avoided in the carbon doping chemistry. (C) 2015 American Vacuum Society.

[http://dx.doi.org/10.1116/1.4914316]
\end{abstract}

\section{INTRODUCTION}

Gallium nitride $(\mathrm{GaN})$ and its alloys are attractive materials for fabricating optoelectronics and high power and high temperature electronics. ${ }^{1,2}$ This is because GaN has a direct wide band gap, a high electric breakdown field and high thermal conductivity.,

To suppress leakage current in $\mathrm{GaN}$ based electronic devices-e.g., high electron mobility transistors (HEMTs) and field effect transistors (FETs) - a semi-insulating buffer layer of $\mathrm{GaN}$ serves an essential role as an isolating barrier between the substrate and the active region of the device. ${ }^{5}$ However, as-grown GaN layers commonly contain residual donors. ${ }^{6}$ Therefore, to obtain semi-insulating properties, the $\mathrm{GaN}$ layer can be intentionally doped with carbon since its acceptor-like properties act to compensate the n-type doping, thereby increasing the resistivity of the layer. ${ }^{7}$ Carbon is also a candidate as a p-type dopant for cubic GaN (Ref. 8) or $\mathrm{AlGaN}$ material. ${ }^{9}$ In addition, the properties of carbon impurities in GaN growth have been intensively studied. ${ }^{10-12}$

The common route to dope $\mathrm{GaN}$ with carbon in chemical vapor deposition (CVD) is to utilize the carbon atoms on the gallium precursor, typically trimethylgallium (TMG) or triethylgallium (TEG). Carbon incorporation from the Ga precursors can be controlled by process parameters such as temperature, pressure, and flow rate of the Ga precursor; more carbon is incorporated when decreasing the temperature or when increasing the TMG/TEG flow. ${ }^{13,14}$ Carbon incorporation is also enhanced at lower pressure. ${ }^{15}$ A second possible source of carbon may be the graphite insulation and graphite susceptor parts if they are not properly coated by a heat resistant material such as tantalum carbide $(\mathrm{TaC})$ or if the protective coating has been damaged. This source of carbon is naturally very hard to control and cannot be used in a reproducible manner.

A major issue when modifying the CVD process parameters to control the carbon incorporation is the risk of operating with nonoptimal CVD process conditions, leading to

a)Electronic mail: xunli@ifm.liu.se
GaN films with rough morphology or bad thickness uniformity. An alternative (and better route to carbon doping of GaN in CVD) is to optimize the process for low residual carbon incorporation and then add a carbon precursor, providing the exact amount of carbon needed for the desired doping. The carbon incorporation in $\mathrm{GaN}$ can then be controlled directly by the flow rate of the carbon precursor, obviating the need to adjust the CVD process parameters too far away from optimal GaN growth. A first choice for a carbon precursor would be one of the many hydrocarbon molecules that are gaseous at room temperature. The simplest hydrocarbon, methane $\left(\mathrm{CH}_{4}\right)$, has been widely used as carbon dopant of GaN grown by molecular beam epitaxy (MBE). ${ }^{16-18}$ However, due to the low reactivity of methane-caused by the highly symmetric geometry of the molecule-it often needs to be decomposed by, for instance, a plasma in the MBE reactor. Other dopants reported for MBE, halide vapor phase epitaxy, or metal organic vapor phase epitaxy are tetrabromomethane $\left(\mathrm{CBr}_{4}\right),{ }^{19,20}$ acetylene $\left(\mathrm{C}_{2} \mathrm{H}_{2}\right),{ }^{21}$ propane $\left(\mathrm{C}_{3} \mathrm{H}_{8}\right),{ }^{22}$ hydrogen cyanide $(\mathrm{HCN}),{ }^{23}$ carbon disulfide $\left(\mathrm{CS}_{2}\right)$, and carbon tetrachloride $\left(\mathrm{CCl}_{4}\right) \cdot{ }^{24}$ However, no thorough comparative investigation of carbon doping efficiency in GaN using different hydrocarbons has been published. Also, very few theoretical calculations regarding hydrocarbon doping efficiency studies have been performed.

In this paper, we present a detailed study of intentional carbon doping of metal organic CVD (MOCVD) grown (0001) GaN using the carbon precursors methane $\left(\mathrm{CH}_{4}\right)$, ethylene $\left(\mathrm{C}_{2} \mathrm{H}_{4}\right)$, acetylene $\left(\mathrm{C}_{2} \mathrm{H}_{2}\right)$, propane $\left(\mathrm{C}_{3} \mathrm{H}_{8}\right)$, iso-butane $\left(\mathrm{i}-\mathrm{C}_{4} \mathrm{H}_{10}\right)$, and trimethylamine $\left[\mathrm{N}\left(\mathrm{CH}_{3}\right)_{3}\right]$. Growth experiments with the dopants have been combined with computational fluid dynamics (CFD) modeling of the gas phase chemistry of the dopants for a more detailed understanding of the carbon incorporation.

\section{METHODS}

\section{A. Experimental details}

$\mathrm{GaN}$ was epitaxially grown upon semi-insulating silicon carbide (4H-SiC) on-axis (0001) substrates with an 
aluminum nitride (AlN) buffer layer in a horizontal hot-wall MOCVD reactor $^{25}$ at a process pressure of 50 mbar. Substrate rotation by gas foil rotation was used. TMG, trimethylaluminum of EpiPure ${ }^{\mathrm{TM}}$ grade, and ammonia $\left(\mathrm{NH}_{3}\right)$ (99.9999\%) were used as precursors for $\mathrm{Ga}, \mathrm{Al}$, and $\mathrm{N}$, respectively, in a mixture of 19 slm hydrogen $\left(\mathrm{H}_{2}\right)$ (99.9996\%) and $3 \mathrm{slm}$ nitrogen $\left(\mathrm{N}_{2}\right)(99.999 \%)$ as the carrier gas. The $90 \mathrm{~nm}$ AlN buffer layer was deposited at $1200^{\circ} \mathrm{C}$. $\mathrm{GaN}$ was grown at lower temperatures, $1000-1100^{\circ} \mathrm{C}$, with a V/III ratio of 1315. During growth, the GaN layer was intentionally carbon doped by adding a certain flow rate of a carbon precursor. The carbon precursors used in this study were methane $\left(\mathrm{CH}_{4}\right)$, ethylene $\left(\mathrm{C}_{2} \mathrm{H}_{4}\right)$, acetylene $\left(\mathrm{C}_{2} \mathrm{H}_{2}\right)$, propane $\left(\mathrm{C}_{3} \mathrm{H}_{8}\right)$, iso-butane $\left(\mathrm{i}-\mathrm{C}_{4} \mathrm{H}_{10}\right)$, and trimethylamine $\left[\mathrm{N}\left(\mathrm{CH}_{3}\right)_{3}\right]$. The first five carbon precursors are common hydrocarbons with simple molecular structures and an increasing number of carbon atoms from 1 to 4 . Trimethylamine is chosen since it resembles both trimethylgallium and ammonia. The $\mathrm{C}_{2} \mathrm{H}_{2}(99.6 \%)$ is diluted to $10 \%$ in $\mathrm{H}_{2}(99.9996 \%)$. All other gases are used without dilution with the purity of $99.9995 \%$ for $\mathrm{CH}_{4}, 99.995 \%$ for $\mathrm{C}_{2} \mathrm{H}_{4}$, $99.95 \%$ for both $\mathrm{C}_{3} \mathrm{H}_{8}$ and $\mathrm{i}-\mathrm{C}_{4} \mathrm{H}_{10}$, and $99 \%$ for $\mathrm{N}\left(\mathrm{CH}_{3}\right)_{3}$, of which major impurities are oxygen and water especially for those than less $99.995 \%$ pure. A purifier is equipped in front of the $\mathrm{N}\left(\mathrm{CH}_{3}\right)_{3}$ to remove oxygen and water to less than $1 \mathrm{ppb}$. In Secs. III A and III B, separate samples with multiple GaN layers (around $200 \mathrm{~nm}$ for every single layer) were grown for each carbon precursor. The flow rate of carbon precursors or GaN growth temperature was changed during the same growth run to achieve the different carbon doping levels. However, $1.2 \mu \mathrm{m}$ thick GaN layers with only one carbon doping level were grown for morphology and structural quality studies (Secs. III D and III E).

Secondary ion mass spectrometry (SIMS) measurements were performed by Evans Analytical Group (using $\mathrm{Cs}^{+}$as primary ions) to obtain the impurity concentrations with a detection limit of $1-2 \times 10^{16} \mathrm{~cm}^{-3}$ for carbon and $5 \times 10^{15} \mathrm{~cm}^{-3}$ for silicon and oxygen. All of the SIMS measurements were performed on the center part of the samples. Surface morphology was characterized by tapping mode atomic force microscopy (AFM). The root mean square (RMS) value of the surface height variation was used to quantify the morphology of the GaN layers. High resolution $\mathrm{x}$-ray diffraction (HRXRD) with a triple-axis configuration was used to evaluate the structural quality of grown $\mathrm{GaN}$ epitaxial layers. A Ge (220) crystal monochromator was used on the primary side, while a Ge (220) triple bounce collimator crystal was used on the secondary side.

\section{B. Computational details}

Gas phase decomposition of various hydrocarbons is very well studied for combustion processes. However, the GaN MOCVD process is free from oxygen, and therefore, the reaction paths will be substantially different from the ones occurring in a combustion process. Since the chemistry of hydrocarbons studied at GaN MOCVD conditions is not easily available in the literature, the chemical composition of the gas phase at relevant process conditions was studied by CFD using a finite-rate chemical kinetic model for the decomposition of the precursors and reactions between the resulting products. This approach was chosen as a better alternative to chemical equilibrium calculations often used to estimate mole fractions of gas phase species in CVD processes. Although process temperatures are relatively high, the time to reach equilibrium in the gas phase is significantly larger $(>10 \mathrm{~s})$ than the residence time in the growth chamber (0.1-1.0 s). Thus, the finite-rate model can provide a more relevant comparison between the different precursors.

Since we are using CFD, the whole CVD reactor could, in principle, be modeled and used in the simulations. However, the complex design of the actual CVD reactor used would lead to very time consuming simulations for solving the flow inside the chamber. Adding heat and chemical models increases the complexity even further. Alternatively, if several simplifications were used they would, inevitably, introduce large uncertainties in the results. Since the purpose of this paper is not to develop a complete and accurate simulation model for carbon incorporation in $\mathrm{GaN}$-but rather to show the difference in doping efficiency for the different hydrocarbons-we have chosen to focus the simulations on the time-development of the gas phase composition at relevant process conditions instead of trying to achieve an exact match to measured results. The simulations used are thus intended to serve as a guide when interpreting the observed different carbon doping efficiencies.

A so-called plug flow reactor ${ }^{26}$ was used as the model geometry for the simulations. In this type of reactor, the flow profile is completely flat (a "plug"), which together with imposed isothermal conditions makes the axial distance of the reactor equal to a time coordinate of the reacting system. The results from the CFD simulations could then be analyzed at a time corresponding to the residence time of the gas in the real CVD reactor.

The finite-rate chemical kinetic model is based on 220 elementary reaction steps taking into account most of the possible hydrocarbon reactions with molecules containing up to four carbon atoms using reaction rates from Refs. 27-33 with an additional 13 reactions accounting for the decomposition of TMG. ${ }^{34}$ It was assumed in the chemical model that $\mathrm{N}_{2}$ and $\mathrm{NH}_{3}$ do not react with the hydrocarbons to any large extent.

The simulations give the gas phase partial pressure for each species in the bulk flow. To study the possible contribution from each species to the carbon doping, we should analyze the composition at the growth surface, which in a CVD system often is different from the bulk flow composition. One way of estimating this is by calculating impingement rates of the species. The impingement rate on the substrate surface can be estimated based on the partial pressure using the expression

$$
\Phi=\frac{p_{i}}{\sqrt{2 \pi M_{i} R T}},
$$

which is derived from the Maxwell-Boltzmann velocity distribution $-p_{i}$ is the partial pressure of species $i$ which is 
given directly by the simulation results, $M_{i}$ is the molecular mass of the species, $R$ is the molar gas constant, and $T$ is the temperature. This expression was used to compare the impingement rates for the same species produced by different carbon precursors.

\section{RESULTS}

\section{A. Carbon precursor flow dependence}

The amount of carbon incorporated in the GaN layers (as measured by SIMS) for an increasing amount of added carbon precursor is shown in Fig. 1. The added carbon precursor is here plotted as "Added $\mathrm{C} / \mathrm{Ga}$ " ratio of the CVD gas mixture since the studied carbon precursors have different amounts of carbon atoms per molecule, and a fixed TMG flow was used. All of the experiments were performed at $1080^{\circ} \mathrm{C}, 50 \mathrm{mbar}$ with a V/III ratio of 1315 . Silicon and oxygen impurities were below the SIMS detection limit in all studied samples. The carbon concentration for undoped samples grown at the same conditions is below the SIMS detection. From Fig. 1, it can be seen that the carbon precursors that lead to the highest carbon incorporation in $\mathrm{GaN}$ are $\mathrm{C}_{2} \mathrm{H}_{2}$ and $\mathrm{C}_{2} \mathrm{H}_{4}$. Hydrocarbons without multiple $\mathrm{C}-\mathrm{C}$ bonds, $\mathrm{C}_{3} \mathrm{H}_{8}$ and $\mathrm{i}-\mathrm{C}_{4} \mathrm{H}_{10}$, give less carbon incorporation as compared to $\mathrm{C}_{2} \mathrm{H}_{2}$ and $\mathrm{C}_{2} \mathrm{H}_{4}$, which have triple and double $\mathrm{C}-\mathrm{C}$ bonds, respectively. The $\mathrm{N}\left(\mathrm{CH}_{3}\right)_{3}$ and $\mathrm{CH}_{4}$ are significantly less efficient in incorporating carbon in the $\mathrm{GaN}$ lattice, with $\mathrm{N}\left(\mathrm{CH}_{3}\right)_{3}$ being somewhat better than $\mathrm{CH}_{4}$.

\section{B. Growth temperature dependence}

The amount of carbon incorporated in the GaN layers, as measured by SIMS, for growth temperatures between 1000 and $1100{ }^{\circ} \mathrm{C}$ is shown in Fig. 2. The growth rate varied from $0.79 \mu \mathrm{m} / \mathrm{h}$ at $1000^{\circ} \mathrm{C}$ to $0.55 \mu \mathrm{m} / \mathrm{h}$ at $1100^{\circ} \mathrm{C}$. The carbon concentration for undoped samples grown at $1050^{\circ} \mathrm{C}$ (or at even higher temperature) was below the SIMS detection limit. The carbon incorporation decreases with higher

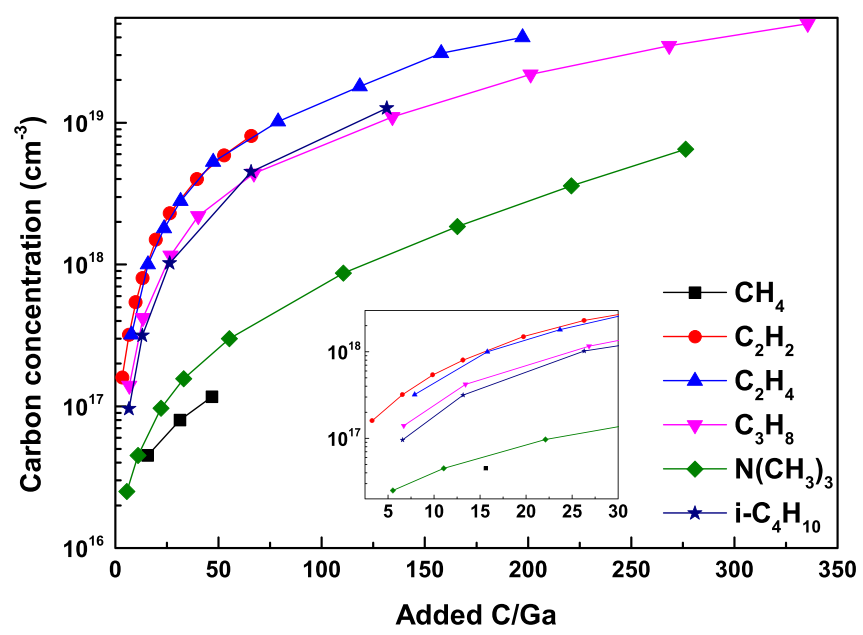

FIG. 1. (Color online) Carbon concentration in intentionally doped $\mathrm{GaN}$ layers from SIMS as a function of Added $\mathrm{C} / \mathrm{Ga}$ when using $\mathrm{CH}_{4}, \mathrm{C}_{2} \mathrm{H}_{2}$, $\mathrm{C}_{2} \mathrm{H}_{4}, \mathrm{C}_{3} \mathrm{H}_{8}, \mathrm{~N}\left(\mathrm{CH}_{3}\right)_{3}$, and $\mathrm{i}-\mathrm{C}_{4} \mathrm{H}_{10}$ as dopants. The growth was done at $1080^{\circ} \mathrm{C}, 50 \mathrm{mbar}$ with a V/III ratio of 1315 , and a growth rate of $0.65 \mu \mathrm{m} / \mathrm{h}$. The inset is a magnified region of the plot with the $\mathrm{C} / \mathrm{Ga}$ ratio up to 30 .

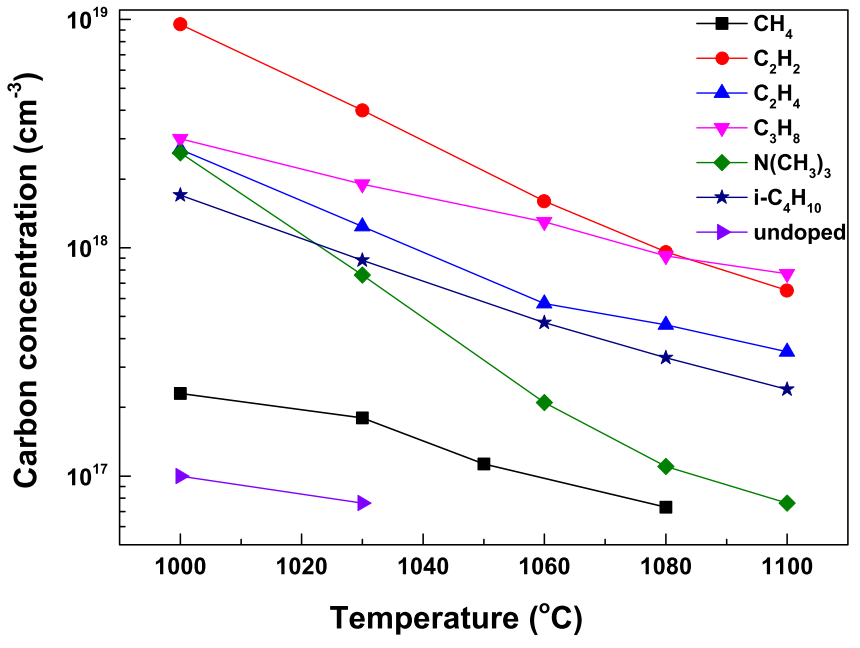

FIG. 2. (Color online) Carbon concentration in intentionally doped GaN layers (by SIMS) as a function of growth temperature. Note that different Added $\mathrm{C} / \mathrm{Ga}$ ratios have been used to give similar carbon incorporation levels for the different carbon precursors, i.e., $\mathrm{CH}_{4} \mathrm{C} / \mathrm{Ga}=31, \mathrm{C}_{2} \mathrm{H}_{2}$ and i- $\mathrm{C}_{4} \mathrm{H}_{10} \mathrm{C} / \mathrm{Ga}=13, \mathrm{C}_{2} \mathrm{H}_{4} \mathrm{C} / \mathrm{Ga}=8, \mathrm{C}_{3} \mathrm{H}_{8}$ and $\mathrm{N}\left(\mathrm{CH}_{3}\right)_{3} \mathrm{C} / \mathrm{Ga}=20$. The process pressure is 50 mbar.

growth temperature for all studied carbon precursors. The hydrocarbons with multiple bonds, $\mathrm{C}_{2} \mathrm{H}_{2}$ and $\mathrm{C}_{2} \mathrm{H}_{4}$, show similar temperature dependence, as does the saturated hydrocarbons, $\mathrm{CH}_{4}, \mathrm{C}_{3} \mathrm{H}_{8}$, and $\mathrm{i}-\mathrm{C}_{4} \mathrm{H}_{10}$. Trimethylamine exhibits the highest variation with temperature.

\section{Gas phase chemistry simulations}

Chemical kinetic simulations (using CFD) were performed at a temperature of $1080^{\circ} \mathrm{C}$ and a pressure of 50 mbar, using different carbon precursors with flow rates varied in line with the experiments. The results show that several different hydrocarbon species are formed in the gas phase. In general, the more stable species $\mathrm{CH}_{4}, \mathrm{C}_{2} \mathrm{H}_{6}, \mathrm{C}_{2} \mathrm{H}_{4}$, and $\mathrm{C}_{2} \mathrm{H}_{2}$ are present in high concentrations, while radical species have low concentrations with the exception of the methyl radical $\mathrm{CH}_{3}$. Depending on which carbon precursor is used, the concentrations of the resulting hydrocarbon species differ. It is also noted that the time to form certain species varies depending on the precursor used due to the different reaction paths and rates for the precursor decomposition. The main initial decomposition reactions are

(1) $\mathrm{CH}_{4}+\mathrm{H} \rightarrow \mathrm{CH}_{3}+\mathrm{H}_{2}$

(2) $\mathrm{C}_{3} \mathrm{H}_{8} \rightarrow \mathrm{C}_{2} \mathrm{H}_{5}+\mathrm{CH}_{3}$

(3) $\mathrm{i}-\mathrm{C}_{4} \mathrm{H}_{10}+\mathrm{CH}_{3} \rightarrow \mathrm{i}-\mathrm{C}_{4} \mathrm{H}_{9}+\mathrm{CH}_{4}$; i- $\mathrm{C}_{4} \mathrm{H}_{9} \rightarrow \mathrm{C}_{3} \mathrm{H}_{6}+\mathrm{CH}_{3}$;

$\mathrm{C}_{3} \mathrm{H}_{6} \rightarrow \mathrm{C}_{2} \mathrm{H}_{3}+\mathrm{CH}_{3}$

(4) $\mathrm{C}_{2} \mathrm{H}_{4} \rightarrow \mathrm{C}_{2} \mathrm{H}_{3}+\mathrm{H} \rightarrow \mathrm{C}_{2} \mathrm{H}_{2}+\mathrm{H}_{2}$.

The decomposition products $\mathrm{C}_{2} \mathrm{H}_{5}$ and $\mathrm{C}_{2} \mathrm{H}_{3}$ in steps (2) and (3) will decompose further to eventually form $\mathrm{C}_{2} \mathrm{H}_{2}$. In summary, $\mathrm{C}_{2} \mathrm{H}_{4}$ mainly decomposes to $\mathrm{C}_{2} \mathrm{H}_{2}, \mathrm{C}_{3} \mathrm{H}_{8}$ and i- $\mathrm{C}_{4} \mathrm{H}_{10}$ yield both $\mathrm{CH}_{3}$ and $\mathrm{CH}_{4}$ as well as $\mathrm{C}_{2} \mathrm{H}_{2}$ and $\mathrm{C}_{2} \mathrm{H}_{4}$, while $\mathrm{CH}_{4}$ yields mainly unreacted $\mathrm{CH}_{4}$ and $\mathrm{CH}_{3}$. Simulations for $\mathrm{C}_{2} \mathrm{H}_{2}$ were not done since it has essentially the same reaction routes as $\mathrm{C}_{2} \mathrm{H}_{4}$, except for the initial steps (4) above. Also, no simulations were done for $\mathrm{N}\left(\mathrm{CH}_{3}\right)_{3}$ 
though this molecule will release $\mathrm{CH}_{3}$, which will transform into $\mathrm{CH}_{4}$, with the reaction routes similar to methane.

To compare the possible contribution from each species to the carbon doping, the impingement rates for all molecules were calculated. These rates were calculated based on the partial pressures given by the simulations at time $\mathrm{t}=0.1 \mathrm{~s}$. This time was determined, by more detailed CFD simulations, to be a representative residence time for the gas in the actual CVD reactor used in the experiments. Figure 3 shows the calculated surface impingement rates for the six most abundant carbon containing species for four different carbon precursors with varying carbon concentration (and constant TMG flow, at $1080^{\circ} \mathrm{C}$ and 50 mbar). It is noted that the impingement rate of $\mathrm{GaCH}_{3}$ remains constant regardless of hydrocarbon flow for all precursors. This implies that there is no $\mathrm{GaCH}_{3}$ formed, e.g., from reactions between free a)

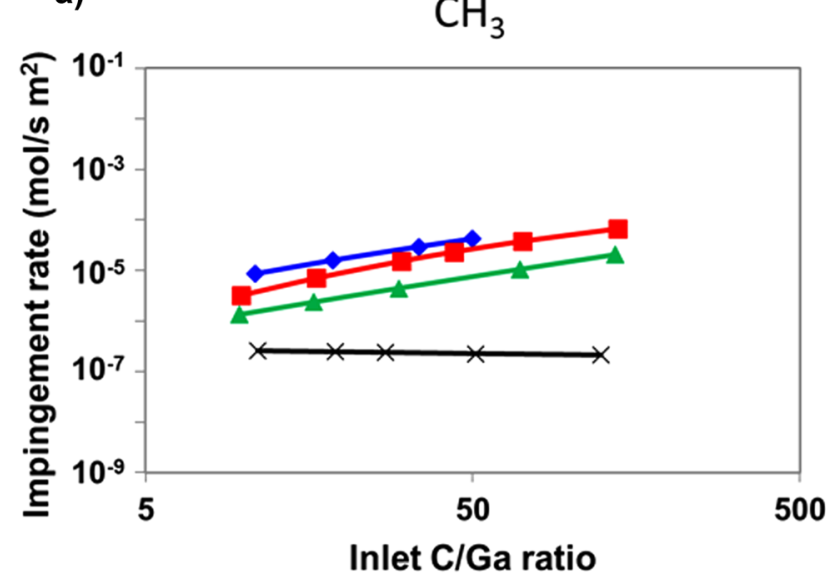

c)

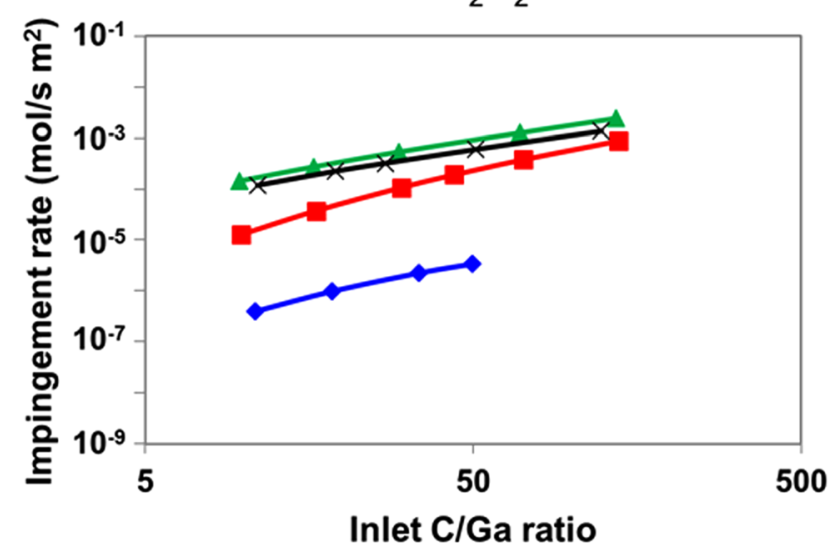

e)

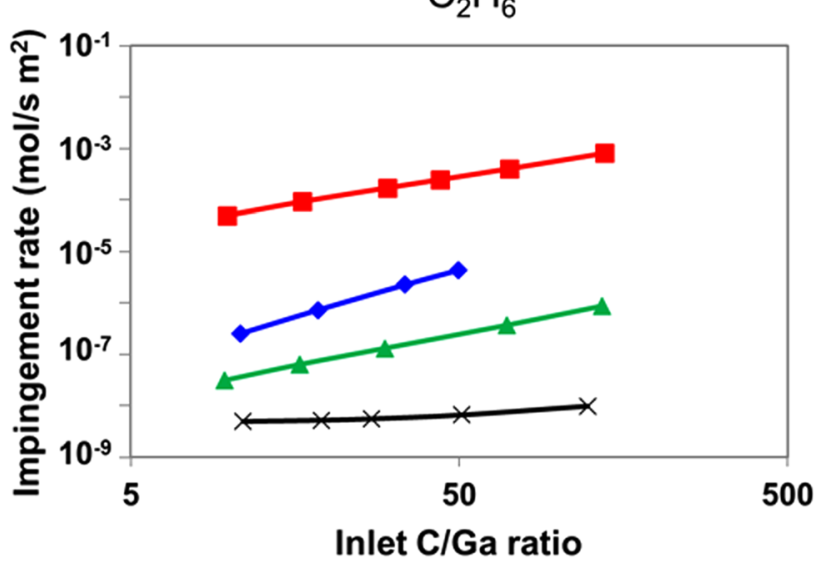

b)

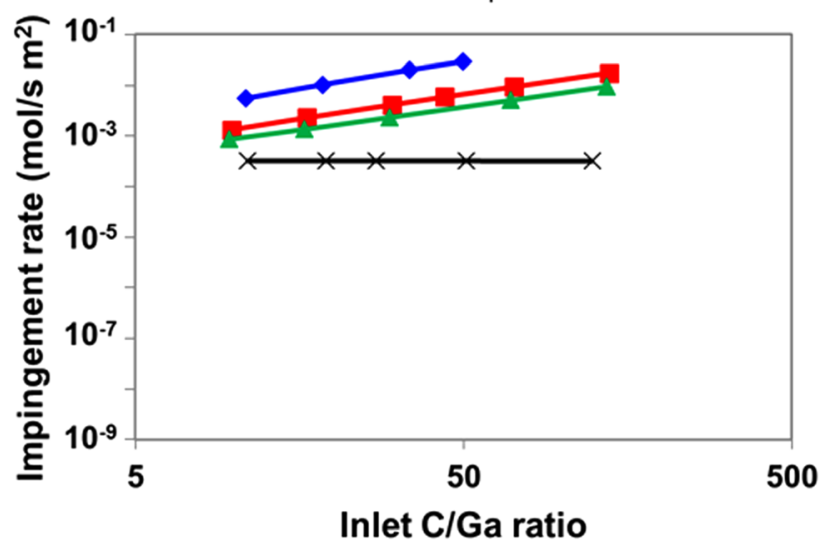

d)

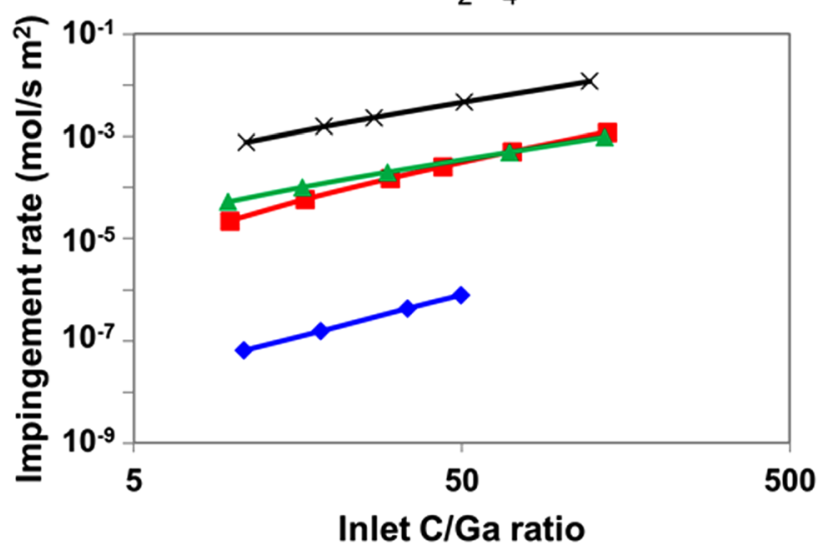

f)

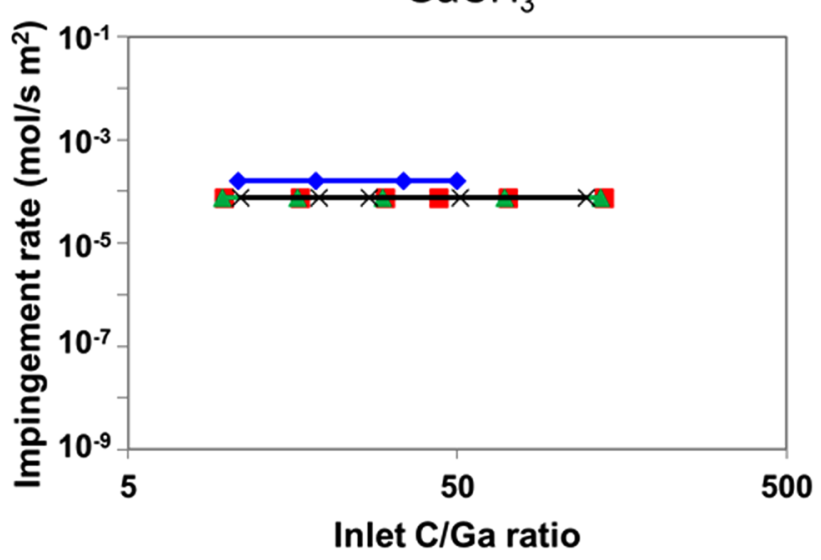

FIG. 3. (Color online) Surface impingement rates of the six most abundant carbon containing species (a) $\mathrm{CH}_{3}$, (b) $\mathrm{CH}_{4}$, (c) $\mathrm{C}_{2} \mathrm{H}_{2}$, (d) $\mathrm{C}_{2} \mathrm{H}_{4}$, (e) $\mathrm{C}_{2} \mathrm{H}_{6}$, and (f) $\mathrm{GaCH}_{3}$ using $\mathrm{CH}_{4}(-\boldsymbol{-}), \mathrm{C}_{3} \mathrm{H}_{8}(-\boldsymbol{-}-)$, i- $\mathrm{C}_{4} \mathrm{H}_{10}(-\boldsymbol{\Delta}-)$, and $\mathrm{C}_{2} \mathrm{H}_{4}(-\times-)$ as carbon precursor, varying the carbon concentration while keeping a constant $\mathrm{TMG}$ flow. Data are taken at time $\mathrm{t}=0.1 \mathrm{~s}$ in the simulations. 
$\mathrm{Ga}$ and hydrocarbons. It is also noted that when using $\mathrm{C}_{2} \mathrm{H}_{4}$ as a precursor, the impingement rates of $\mathrm{CH}_{3}$ and $\mathrm{CH}_{4}$ are essentially constant, indicating that decomposition of $\mathrm{C}_{2} \mathrm{H}_{4}$ does not lead to formation of these molecules.

\section{Morphology}

Figure 4 shows the typical $3 \times 3 \mu \mathrm{m}^{2}$ AFM images of $1.2 \mu \mathrm{m}$ thick $\mathrm{GaN}$ epitaxial layers intentionally doped with carbon by different carbon precursors $\mathrm{CH}_{4}, \mathrm{C}_{2} \mathrm{H}_{2}, \mathrm{C}_{2} \mathrm{H}_{4}$, $\mathrm{C}_{3} \mathrm{H}_{8}, \mathrm{i}-\mathrm{C}_{4} \mathrm{H}_{10}$, and $\mathrm{N}\left(\mathrm{CH}_{3}\right)_{3}$, respectively. When using $\mathrm{CH}_{4}$ as a dopant, hexagonal pits start to appear on the GaN surface with carbon concentration around $8 \times 10^{16} \mathrm{~cm}^{-3}$ [Fig. 4(a)]. Similar defects are observed for samples with carbon concentration higher than $9 \times 10^{17} \mathrm{~cm}^{-3}$ doped by $\mathrm{N}\left(\mathrm{CH}_{3}\right)_{3}$ gas [Fig. 4(f)]. The depth of the pits is generally from 20 to $100 \mathrm{~nm}$. When using the other four dopants $\mathrm{C}_{2} \mathrm{H}_{2}, \mathrm{C}_{2} \mathrm{H}_{4}$,
$\mathrm{C}_{3} \mathrm{H}_{8}$, and $\mathrm{i}-\mathrm{C}_{4} \mathrm{H}_{10}, \mathrm{GaN}$ layers with good step flow morphology are achieved with the carbon concentration in the range of $10^{18} \mathrm{~cm}^{-3}$ [Figs. 4(b)-4(e)].

\section{E. Structural quality}

HRXRD rocking curve analysis was performed in order to evaluate the structural quality of the GaN epitaxial layers. Full width half maximum (FWHM) values were extracted for both (002) and (102) reflections, which revealed screw and edge types of threading dislocations. ${ }^{35}$ Figure 5 shows the HRXRD data for samples grown at $1080^{\circ} \mathrm{C}$. As a general trend, the FWHM of the XRD rocking curve peaks increase (i.e., indicating that the crystal quality degraded) with increased carbon concentration in the GaN layers. For carbon concentrations in the $10^{17} \mathrm{~cm}^{-3}$ range, $\mathrm{N}\left(\mathrm{CH}_{3}\right)_{3}$ is the precursor that affects the $\mathrm{GaN}$ lattice the least, while for
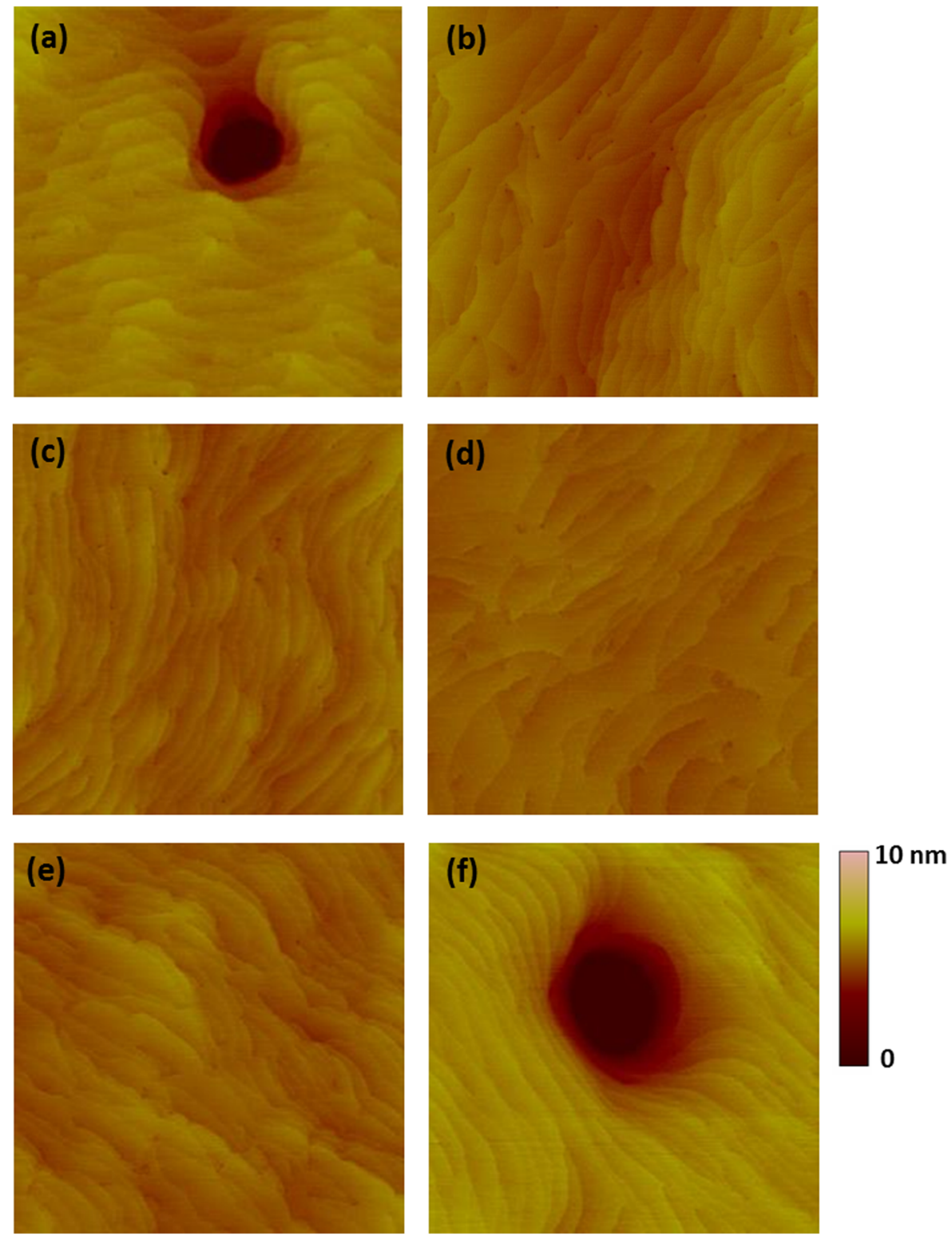

FIG. 4. (Color online) AFM images $\left(3 \times 3 \mu \mathrm{m}^{2}\right)$ of $1.2 \mu \mathrm{m}$ thick GaN layers intentionally doped with carbon using (a) $\mathrm{CH}_{4}$, (b) $\mathrm{C}_{2} \mathrm{H}_{2}$, (c) $\mathrm{C}_{2} \mathrm{H}_{4}$, (d) $\mathrm{C}_{3} \mathrm{H}_{8}$, (e) i-

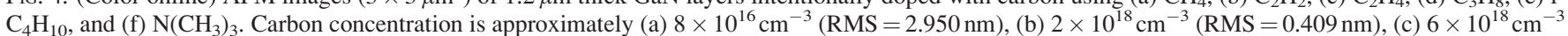
$($ RMS $=0.273 \mathrm{~nm}),\left(\right.$ d) $5 \times 10^{18} \mathrm{~cm}^{-3}(\mathrm{RMS}=0.178 \mathrm{~nm}),(\mathrm{e}) 5 \times 10^{18} \mathrm{~cm}^{-3}(\mathrm{RMS}=0.272 \mathrm{~nm})$, and (f) $9 \times 10^{17} \mathrm{~cm}^{-3}(\mathrm{RMS}=2.397 \mathrm{~nm})$, respectively. 


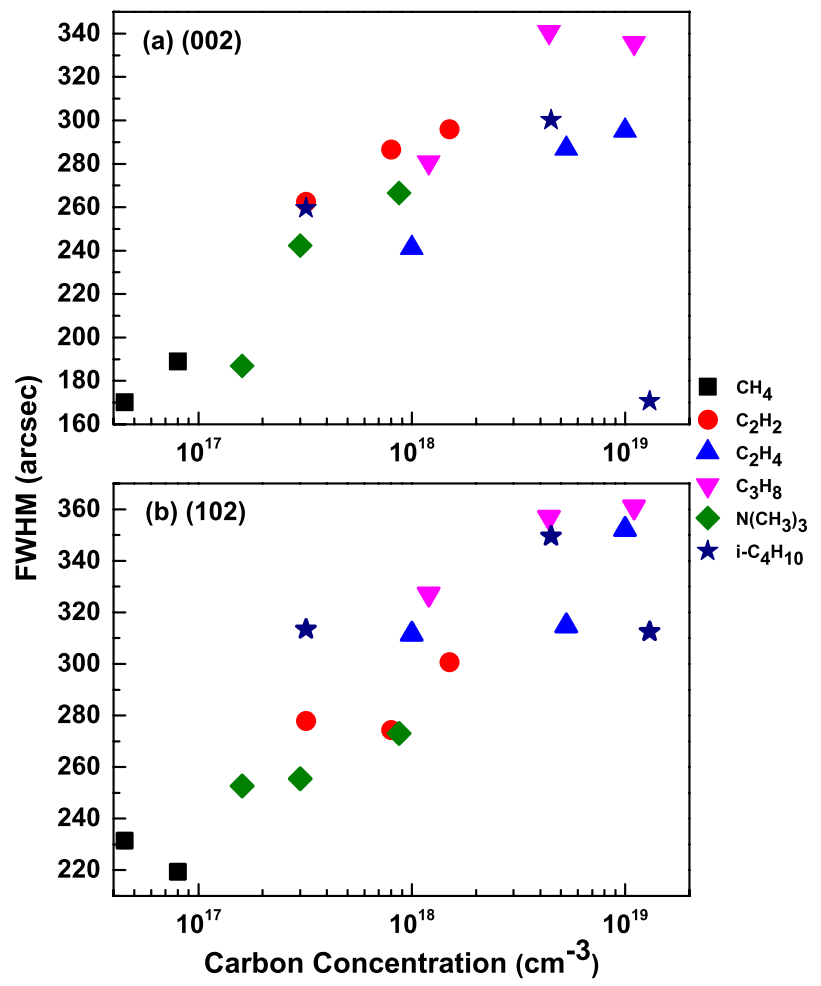

FIG. 5. (Color online) FWHM values extracted from HRXRD. Plots (a) (002) and (b) (102) show rocking curves as function of carbon concentration for GaN layers using $\mathrm{CH}_{4}, \mathrm{C}_{2} \mathrm{H}_{2}, \mathrm{C}_{2} \mathrm{H}_{4}, \mathrm{C}_{3} \mathrm{H}_{8}, \mathrm{i}-\mathrm{C}_{4} \mathrm{H}_{10}$, and $\mathrm{N}\left(\mathrm{CH}_{3}\right)_{3}$ as dopants, respectively.

carbon concentrations in the $10^{18} \mathrm{~cm}^{-3}$ range, $\mathrm{C}_{2} \mathrm{H}_{4}$ and i- $\mathrm{C}_{4} \mathrm{H}_{10}$ are the carbon precursors with the lowest impact on crystal quality. The very low FWHM for (002) when using i- $\mathrm{C}_{4} \mathrm{H}_{10}$ to get a carbon concentration in the $10^{19} \mathrm{~cm}^{-3}$ range is possibly due to a change in growth mode from step flow to island growth (as indicated by the AFM images) imposed by the carbon doping of the GaN. For typical undoped samples grown at the same condition, FWHM value is around 180 and $210 \mathrm{arc} \sec$ for (002) and (102) reflections, respectively.

\section{DISCUSSION}

High carbon incorporation efficiency without compromising the crystal quality should be the key factor when choosing a precursor for carbon doping of GaN. From the experimental results, we see that the unsaturated hydrocarbons $\mathrm{C}_{2} \mathrm{H}_{2}$ and $\mathrm{C}_{2} \mathrm{H}_{4}$ have the highest carbon incorporation efficiency followed by the saturated hydrocarbons $\mathrm{C}_{3} \mathrm{H}_{8}$ and i- $\mathrm{C}_{4} \mathrm{H}_{10}$ (Fig. 1). From the computational results, i.e., reaction (4), we see that $\mathrm{C}_{2} \mathrm{H}_{4}$ forms $\mathrm{C}_{2} \mathrm{H}_{2}$ in the CVD reactor. The high carbon incorporation efficiency of both $\mathrm{C}_{2} \mathrm{H}_{4}$ and $\mathrm{C}_{2} \mathrm{H}_{2}$ thus suggests that the $\mathrm{C}_{2} \mathrm{H}_{2}$ molecule is well suited for incorporating carbon in the GaN lattice. The saturated hydrocarbons are found to react mainly to methyl $\left(\mathrm{CH}_{3}\right)$ and $\mathrm{C}_{2} \mathrm{H}_{2}$, i.e., reactions (2) and (3). The good carbon incorporation efficiency for the saturated hydrocarbons should thus be ascribed to the formation of $\mathrm{C}_{2} \mathrm{H}_{2}$. The simplest hydrocarbon methane $\left(\mathrm{CH}_{4}\right)$ has very low carbon incorporation efficiency. This can be explained by the very high symmetry in the molecule, making it rather unreactive. When it does react, it forms the highest concentration of $\mathrm{CH}_{3}$ among the hydrocarbons, i.e., reaction (1). Trimethylamine, $\mathrm{N}\left(\mathrm{CH}_{3}\right)_{3}$, is a molecule that resembles ammonia, $\mathrm{NH}_{3}$, in that it has nitrogen as the central atom, but also TMG as both have the central atom surrounded by three methyl groups. $\mathrm{N}\left(\mathrm{CH}_{3}\right)_{3}$ is therefore potentially interesting as a carbon dopant since it can be expected to find a place in the growth chemistry of GaN. However, we see from Fig. 1 that $\mathrm{N}\left(\mathrm{CH}_{3}\right)_{3}$ is not as efficient in carbon incorporation as the hydrocarbon molecules. The very low carbon incorporation efficiency for $\mathrm{CH}_{4}$ and the low efficiency for $\mathrm{N}\left(\mathrm{CH}_{3}\right)_{3}$ indicates that the $\mathrm{CH}_{3}$ molecule is not a suitable molecule to incorporate carbon in the $\mathrm{GaN}$ lattice; thus, the carbon precursors that supply carbon mainly in the form of $\mathrm{CH}_{3}$ are not good precursors for carbon doping of GaN. In this light, the saturated hydrocarbons cannot be regarded as the best choice since they, in addition to $\mathrm{C}_{2} \mathrm{H}_{2}$, form a substantial amount of $\mathrm{CH}_{3}$. Furthermore, the fact that $\mathrm{CH}_{3}$ groups are not effective dopants also explains why carbon doping can be controlled by other molecules even in the presence of orders of magnitude higher concentrations of $\mathrm{CH}_{3}$ originating from the Ga precursor TMG. The saturated hydrocarbons show more stable carbon incorporation efficiency with temperature than the unsaturated hydrocarbons. This is especially clear in the temperature range of $1000-1060^{\circ} \mathrm{C}$. The least stable carbon incorporation with temperature is displayed for $\mathrm{N}\left(\mathrm{CH}_{3}\right)_{3}$, which further indicates that it is not suited as a carbon precursor for $\mathrm{GaN}$.

The morphology of $\mathrm{GaN}$ epitaxial layers doped with $\mathrm{CH}_{4}$ and $\mathrm{N}\left(\mathrm{CH}_{3}\right)_{3}$ exhibits high surface roughness and large pits formed on epitaxial layers even when carbon concentration is below $10^{18} \mathrm{~cm}^{-3}$ (Fig. 4). The formation of the pits is not yet understood. For the other dopants, the surface morphology is not significantly affected by the carbon doping and the growth mode remains as "step flow" without any obvious defects up to a carbon concentration of $10^{19} \mathrm{~cm}^{-3}$ (Fig. 4).

The structural quality of the GaN layers as quantified by the FWHM of the (002) and (102) GaN XRD peaks shows that the crystal quality will decrease when adding carbon to the lattice. Though not surprising, the results in Fig. 5 indicate that the degradation of the crystal quality can be somewhat limited by proper selection of a carbon precursor. The unsaturated hydrocarbons again show better results than the saturated hydrocarbons at high carbon incorporation $\left(10^{19} \mathrm{~cm}^{-3}\right.$ range), while $\mathrm{N}\left(\mathrm{CH}_{3}\right)_{3}$ gives the lowest FWHM of carbon incorporation in the low $10^{18} \mathrm{~cm}^{-3}$ range.

The unsaturated hydrocarbons seem to be the best carbon precursors for carbon doping of $\mathrm{GaN}$ when adding together the results on carbon incorporation efficiency and the effect on morphology and structural quality. Since the $\mathrm{C}_{2} \mathrm{H}_{2}$ molecule seems to be the key species for carbon incorporation, it is tempting to declare that as the best carbon precursor. But given the low purity available for $\mathrm{C}_{2} \mathrm{H}_{2}, \mathrm{C}_{2} \mathrm{H}_{4}$ is the preferred carbon precursor for carbon doping of $\mathrm{GaN}$.

This study is made using a GaN CVD process optimized for HEMTs and FETs, which is where carbon doping can make a significant impact. The growth rate used is normal for these applications since the thickness of the GaN layer needed is $\sim 2 \mu \mathrm{m}$. Other applications for GaN CVD will 
require a high growth rate which will mainly be achieved by a higher concentration of precursors. We speculate that the carbon doping efficiency from the studied precursors will not be affected by higher precursor flows as the differences in gas phase and surface chemistry between the carbon precursors are not likely to change with higher flows of the precursors.

\section{SUMMARY}

In this work, six hydrocarbon precursors, i.e., $\mathrm{CH}_{4}, \mathrm{C}_{2} \mathrm{H}_{2}$, $\mathrm{C}_{2} \mathrm{H}_{4}, \mathrm{C}_{3} \mathrm{H}_{8}$, i- $\mathrm{C}_{4} \mathrm{H}_{10}$, and $\mathrm{N}\left(\mathrm{CH}_{3}\right)_{3}$, were studied for intentional carbon doping of MOCVD grown $\mathrm{GaN}$. The unsaturated hydrocarbons $\mathrm{C}_{2} \mathrm{H}_{2}$ and $\mathrm{C}_{2} \mathrm{H}_{4}$ have the highest carbon incorporation efficiency and result in a rather good morphology and crystal quality for $\mathrm{GaN}$ epitaxial layers. Saturated hydrocarbon $\mathrm{C}_{3} \mathrm{H}_{8}$ and $\mathrm{i}-\mathrm{C}_{4} \mathrm{H}_{10}$ have the second highest incorporation efficiency, whereas $\mathrm{CH}_{4}$ is the lowest. CFD modeling further suggests that the $\mathrm{C}_{2} \mathrm{H}_{2}$ molecule, as supplied directly or as formed from $\mathrm{C}_{2} \mathrm{H}_{4}$, is a key species for incorporating carbon in the $\mathrm{GaN}$ lattice. The $\mathrm{CH}_{3}$ species, formed from the saturated hydrocarbon molecules, seem to degrade both the morphology and structural quality of $\mathrm{GaN}$ and is not as effective for carbon incorporation in $\mathrm{GaN}$ as the $\mathrm{C}_{2} \mathrm{H}_{2}$ molecule. Finally, it is suggested that $\mathrm{C}_{2} \mathrm{H}_{4}$ is the best precursor for carbon doping of $\mathrm{GaN}$.

\section{ACKNOWLEDGMENTS}

Sankara Pillay is gratefully acknowledged for critically reading and revising the manuscript. Generous financial support from the Swedish Foundation for Strategic Research (SSF) and the Swedish Defence Materiel Administration (FMV) is gratefully acknowledged.

${ }^{1}$ M. H. Crawford, IEEE J. Sel. Top. Quantum Electron. 15, 1028 (2009).

${ }^{2}$ J. Millán, P. Godignon, X. Perpiñà, A. Pérez-Tomás, and J. Rebollo, IEEE Trans. Power Electron. 29, 2155 (2014).

${ }^{3}$ A. A. Lebedev and V. E. Chelnokov, Semiconductors 33, 999 (1999).

${ }^{4}$ S. N. Mohammad and H. Morkoc, Prog. Quantum Electron. 20, 361 (1996).

${ }^{5}$ M. J. Uren, IEEE Trans. Electron Devices 59, 3327 (2012).
${ }^{6}$ X. Xu, H. Liu, C. Shi, Y. Zhao, S. Fung, and C. D. Beling, J. Appl. Phys. 90, 6130 (2001).

${ }^{7}$ A. Armstrong, A. R. Arehart, B. Moran, S. P. DenBaars, U. K. Mishra, J. S. Speck, and S. A. Ringel, Appl. Phys. Lett. 84, 374 (2004).

${ }^{8}$ A. Zado, E. Tschumak, J. W. Gerlach, K. Lischka, and D. J. As, J. Cryst. Growth 323, 88 (2011).

${ }^{9}$ H. Kawanishi and T. Tomizawa, Phys. Status Solidi B 249, 459 (2012).

${ }^{10}$ P. D. Mierry, O. Ambacher, H. Kratzer, and M. Stutzmann, Phys. Status Solidi A 158, 587 (1996).

${ }^{11}$ O. Ambacher, W. Rieger, P. Ansmann, H. Angerer, T. D. Moustakas, and M. Stutzmann, Solid State Commun. 97, 365 (1996).

${ }^{12}$ F. Kawamura, M. Morishita, M. Tanpo, M. Imade, M. Yoshimura, Y. Kitaoka, Y. Mori, and T. Sasaki, J. Cryst. Growth 310, 3946 (2008).

${ }^{13}$ G. Parish, S. Keller, S. P. Denbaars, and U. K. Mishra, J. Electron. Mater. 29, 15 (2000).

${ }^{14}$ A. Ishibashi, H. Takeishi, M. Mannoh, Y. Yabuuchi, and Y. Ban, J. Electron. Mater. 25, 799 (1996).

${ }^{15}$ D. D. Koleske, A. E. Wickenden, R. L. Henry, and M. E. Twigg, J. Cryst. Growth 242, 55 (2002).

${ }^{16}$ S. Haffouz, H. Tang, J. A. Bardwell, E. M. Hsu, J. B. Webb, and S. Rolfe, Solid-State Electron. 49, 802 (2005).

${ }^{17}$ S. Haffouz, H. Tang, S. Rolfe, and J. A. Bardwell, Appl. Phys. Lett. 88, 252114 (2006).

${ }^{18}$ M. R. Ramdani, M. Chmielowska, Y. Cordier, S. Chenot, and F. Semond, Solid-State Electron. 75, 86 (2012).

${ }^{19}$ C. Poblenz, P. Waltereit, S. Rajan, S. Heikman, U. K. Mishra, and J. S. Speck, J. Vac. Sci. Technol. B 22, 1145 (2004).

${ }^{20}$ G. Koblmüller, R. M. Chu, A. Raman, U. K. Mishra, and J. S. Speck, J. Appl. Phys. 107, 043527 (2010).

${ }^{21}$ N. Koide, T. Hikosaka, Y. Honda, M. Yamaguchi, and N. Sawaki, J. Cryst. Growth 284, 341 (2005).

${ }^{22}$ R. Zhang and T. F. Kuech, Appl. Phys. Lett. 72, 1611(1998).

${ }^{23}$ D. Gogova, G. Yu. Rudko, D. Siche, M. Albrecht, K. Irmscher, H.-J. Rost, and R. Fornari, Phys. Status Solidi C 8, 2120 (2011).

${ }^{24}$ R. Armitage, Q. Yang, H. Feick, and E. R. Weber, J. Cryst. Growth 263, 132 (2004).

${ }^{25}$ U. Forsberg, A. Lundskog, A. Kakanakova-Georgieva, R. Ciechonski, and E. Janzén, J. Cryst. Growth 311, 3007 (2009).

${ }^{26}$ R. B. Bird, W. E. Stewart, and E. N. Lightfoot, Transport Phenomena (Wiley, New York, 2007).

${ }^{27}$ W. Tsang and R. F. Hampson, J. Phys. Chem. Ref. Data 15, 1087 (1986).

${ }^{28}$ W. Tsang, J. Phys. Chem. Ref. Data 17, 887 (1988).

${ }^{29}$ W. Tsang, J. Phys. Chem. Ref. Data 19, 1 (1990).

${ }^{30}$ W. Tsang, J. Phys. Chem. Ref. Data 20, 221 (1991).

${ }^{31}$ D. L. Baulch et al., J. Phys. Chem. Ref. Data 21, 411 (1992).

${ }^{32}$ D. L. Baulch et al., J. Phys. Chem. Ref. Data 23, 847 (1994).

${ }^{33}$ D. L. Baulch et al., J. Phys. Chem. Ref. Data 34, 757 (2005).

${ }^{34}$ D. Sengupta, S. Mazumder, W. Kuykendall, and S. A. Lowry, J. Cryst. Growth 279, 369 (2005).

${ }^{35}$ M. A. Moram and M. E. Vickers, Rep. Prog. Phys. 72, 036502 (2009). 